\title{
Mining the EU Global Strategy of 2016
}

\section{Introduction}

As with many data-driven research experiments, this one was conducted without formulating any research questions prior to the analysis. Those have appeared at a later stage and constituted a departure point for the discussion on the usefulness of text mining techniques for the interpretation of bureaucratic documents as well as allowing for the identification of several issues which have been either overlooked (e.g. highlighting the importance of research) or underestimated (e.g. the concept of sustainability or the role of human rights). Nonetheless, the lexical analysis confirmed many previous findings, such as the ambition to strengthen defence capabilities within the EU as well as the central role of the concept of resilience. Hence, this study claims that text mining techniques can supplement traditional means of interpretation, especially when the volume and granularity of the document(s) result in incoherent interpretations and, as a consequence, hinder the process of its operationalization. Another added value of this study is the introduction of complex systems theory for the interpretation of the EUGS leitmotif, namely the concept of resilience. The textual analysis has shown that the lexical layer of the recent strategy is distinctive for studies that build upon systems theory, regardless of the scientific discipline. This refers to such terms as resilience, sustainability or cooperation, which 
are indeed a bridge between the textual and the conceptual levels of understanding the document. Thus, the latter part of this paper introduces complex systems theory to the interpretation of the concept of resilience which, although named as a leitmotif of the strategy of 2016, raises doubts over its factual meaning and, as a consequence, over its usefulness for EU policymakers. Particular emphasis have been put on the interplay between the concepts of resilience and human rights, which are on the agenda of both the EU and the UN.

\section{Methods}

This paper proposes the application of an automated lexical analysis using Statistica software (StatSoft v. 13). ${ }^{1}$ Lexical analysis is one of the text mining techniques aimed at the extraction of meaningful information from natural language texts. Text mining, which is a response to the problem of large amounts of textual data, has been already recognized as a useful tool for policymakers by the various EU institutions. ${ }^{2}$ Although text mining techniques are usually applied to the large amounts of data, they may provide an insightful contribution to the analysis of single documents as well, as this paper aims to prove. Moreover, they allow for drawing evidence-based conclusions while keeping them brief and, thus, may serve as a handy resource for policymakers. Lastly, text mining allows for pointing out the similarities and differences between the relevant documents and emphasizes shifts or trends reflected in the language.

This study is based on a lexical analysis of the EU's security strategies: the EU Security Strategy of 2003 and the EU Global Strategy 2016 (hereafter: EUGS). The lexical analysis included calculating term frequency (measuring how frequently a term occurs in each document sep-

1 TIBCO Statistica, <http://statistica.io/>.

2 The European Commission's Science and Knowledge Service, Competence Centre on Text Mining and Analysis, <https://ec.europa.eu/jrc/en/text-mining-and-analysis>. 
arately) as well as inverse term frequency (measuring the importance of the term in a collection of documents; also known as TF-IDF). The latter may often give more meaningful results than a classical term frequency analysis. ${ }^{3}$ All the stop words (e.g. a, an, the, on) were excluded from the research. Both texts have been cleaned, e.g. by removing repeated paragraphs and headers. The analysis was conducted before and after applying lemmatization (thus, the results are presented in two separate tables).

\section{Results}

Text mining analysis allowed the creation of two separate term-document matrices describing term frequency in each document, and a joint matrix measuring inverse term frequency in both documents. Based on all three matrices, the most significant terms have been selected and presented in Table 1 (the list of terms after applying the lemmatization of words) and Table 2 (the list of terms without applying lemmatization). The terms were selected according to three criteria: 1) high term frequency in at least one of the documents, 2) high TF-IDF score, and 3) significance for the topic of EU defence and security policy. The terms have been listed in alphabetical order. When interpreting the results, it is important to keep in mind that the EU Global Strategy of 2016 contains about three times more words than its predecessor (15,496 compared to 4,197 words). Hence, there are relatively large differences in the overall number of mentions.

3 G. Salton, M.J. MacGill, Introduction to Modern Information Retrieval, McGraw-Hill 1983, p. 63; J. Ramos, Using TF-IDF to Determine Word Relevance in Document Queries, 1999. 
Table 1. List of the 10 most relevant terms (after applying lemmatization of words) showing the differences in the lexical layers between the EU's security strategies of 2003 and 2016. Words were extracted based on the frequency rank and TF-IDF score. Source: the author's own elaboration.

\begin{tabular}{|l|c|c|c|c|c|c|}
\hline \multirow{2}{*}{ Term } & \multicolumn{3}{|c|}{ Strategy of 2003} & \multicolumn{3}{c|}{ Strategy of 2016} \\
\cline { 2 - 7 } & Rank & $\begin{array}{l}\text { Term } \\
\text { Freq. }\end{array}$ & TF-IDF & Rank & $\begin{array}{c}\text { Term } \\
\text { Freq. }\end{array}$ & TF-IDF \\
\hline cooper (e.g. cooperation) & 48 & 8 & - & 5 & 74 & - \\
\hline cyber & - & - & - & 74 & 21 & 2,73 \\
\hline deal & 32 & 12 & - & 493 & 3 & - \\
\hline defen (e.g. defence) & 40 & 9 & - & 15 & 51 & - \\
\hline democra (e.g. democracy) & 97 & 5 & - & 74 & 21 & - \\
\hline diploma (e.g. diplomacy) & - & - & - & 47 & 27 & 2,90 \\
\hline econom (e.g. economy) & 58 & 7 & - & 23 & 42 & 2,29 \\
\hline object (e.g. objective) & 57 & 7 & 2,04 & - & 0 & - \\
\hline principle (e.g. principles) & - & - & - & 46 & 28 & 3,00 \\
\hline resili (e.g. resilience) & - & - & - & 36 & 35 & 3,16 \\
\hline
\end{tabular}

Table 2. List of the 22 most relevant terms (without applying lemmatization) showing the differences in the lexical layers between the EU's security strategies of 2003 and 2016. Words were extracted based on the frequency rank and TFIDF score. Source: the author's own elaboration.

\begin{tabular}{|l|c|c|c|c|c|c|}
\hline \multirow{2}{*}{ Term } & \multicolumn{3}{|c|}{ Strategy of 2003 } & \multicolumn{3}{c|}{ Strategy of 2016} \\
\cline { 2 - 7 } & Rank & $\begin{array}{c}\text { Term } \\
\text { Freq. }\end{array}$ & TF-IDF & Rank & $\begin{array}{c}\text { Term } \\
\text { Freq. }\end{array}$ & TF-IDF \\
\hline can & 10 & 17 & - & 19 & 37 & - \\
\hline climate & - & - & - & 42 & 24 & 2,90 \\
\hline conflict & 8 & 19 & - & 42 & 24 & - \\
\hline conflicts & 35 & 9 & - & 43 & 23 & - \\
\hline counter-terrorism & - & - & - & 133 & 11 & 2,36 \\
\hline crisis & 29 & 10 & - & 153 & 10 & - \\
\hline crises & 371 & 1 & - & 61 & 20 & - \\
\hline
\end{tabular}


Mining the EU Global Strategy... | 211

\begin{tabular}{|l|c|c|c|c|c|c|}
\hline \multirow{2}{*}{ Term } & \multicolumn{3}{|c|}{ Strategy of 2003 } & \multicolumn{3}{c|}{ Strategy of 2016 } \\
\cline { 2 - 7 } & Rank & $\begin{array}{c}\text { Term } \\
\text { Freq. }\end{array}$ & TF-IDF & Rank & $\begin{array}{c}\text { Term } \\
\text { Freq. }\end{array}$ & TF-IDF \\
\hline development & 29 & 10 & - & 11 & 55 & - \\
\hline distant & 110 & 4 & 1,65 & - & - & - \\
\hline energy & 74 & 5 & - & 18 & 39 & \\
\hline human rights & 221 & 2 & - & 38 & 26 & - \\
\hline Member States & 51 & 6 & - & 13 & 44 & - \\
\hline migration & - & - & - & 53 & 22 & 2,84 \\
\hline must & 221 & 2 & - & 7 & 65 & - \\
\hline problems & 16 & 14 & 2,52 & - & 0 & - \\
\hline research & - & - & - & 133 & 11 & 2,36 \\
\hline security & 2 & 31 & - & 3 & 128 & - \\
\hline should & 8 & 19 & - & 121 & 12 & - \\
\hline sustainable & - & - & - & 26 & 31 & 3,07 \\
\hline threat & 29 & 10 & - & 336 & 5 & - \\
\hline threats & 5 & 24 & - & 121 & 12 & - \\
\hline will & 15 & 15 & - & 1 & 274 & - \\
\hline
\end{tabular}

\section{Discussion \\ Tone: 'Yes, We Can' or 'We Must'?}

There were few comparative lexical studies touching on the differences between the current and previous EU strategies in the areas of defence and security. Yet even a cursory analysis of both documents highlights striking differences in their lexical layers. The introduction to the strategy of 2003 starts with the statement that "Europe has never been so prosperous, so secure nor so free" ${ }^{4}$ and such a conviction - that Europe is doing well - was reflected in the language used in the docu-

4 Council of the European Union, European Security Strategy: A Secure Europe in a Better World, Brussels, 2003, p. 2. 
ment. One may say the tone was enthusiastic, as the strategy called for being "more active in pursuing our strategic objectives"5 and concluded that " $[\mathrm{t}]$ his is a world of new dangers but also of new opportunities." 6 The most frequently occurring verbs were: should (8th most frequently mentioned word), can (10th) and will (15th). These are used to express recommendation (should), underline capacity (can), and set an objective $^{7}$ or express future action (will). Significantly, none of them expresses necessity. The latter, associated with the word must, remained almost absent as it was used only twice in the document (221st).

The situation with the EUGS is quite the opposite. While the most frequently used word in the whole document is will, the word must was ranked 7th (and, simultaneously, the second most common verb). At the same time, the frequency of the verbs can and should decreased significantly (to 19th and 121st respectively). This striking inversion of proportions confirms that the current strategy is not limited to the identification of possible objectives but underlines the necessity and urgency in addressing threats. The overall tone of the EUGS is far more pessimistic - suffice it to cite the opening sentence: "The purpose, even existence, of our Union is being questioned."

Similarly, the analysis of lexical layers reflects different scale of the challenges that the EU was tackling in 2003 and is facing now. Under the previous strategy, the most frequent terms used to describe challenges were threats (5th most frequently occurred in the document) and problems (16th). The former implies rather the possibility than the actual existence of dangerous occurrence. The latter clearly refers to the present situations regarded as unwelcome, however remains a relatively soft expression and, most of all, suggests that the difficulties are pos-

\footnotetext{
5 Ibidem, 11.

6 Ibidem, 14.

7 Interestingly, the term 'objective(s)', while being present in the Strategy of 2003, is absent in the EUGS. Therefore, this term has been indicated as a relevant for the Strategy of 2003 with the TF-IDF score $(2,04)$.

8 Council of the European Union, European Security Strategy, 14.
} 
sible to overcome. The EUGS, on the other hand, operates mostly with the terms conflicts (23 mentions) and crises (20 mentions) ${ }^{9}$, while problems does not appear even once, and the frequency of threats significantly decreased (12 mentions). Hence, the rhetoric of the EUGS is much tougher and corresponds with the urgency emphasized in the previous part of this study. Moreover, the EUGS operates mostly with the plural forms (crises, conflicts) while under the strategy of 2003 singular forms of these words clearly prevailed (crisis, conflict).

Furthermore, the EUGS emphasizes the global character of challenges and the need for internal cooperation (between the Member States) and external cooperation (notably with the United States, United Nations, and NATO) when tackling them. Under the previous strategy, the issue of cooperation was marginalized and limited to external relations only. Its revival is arguably a consequence of diagnosing the interdependence of internal and external threats, the need for greater coherence between the policies of the EU and Member States ${ }^{10}$, as well as the belief that none of the EU countries is able to address current threats alone. ${ }^{11}$ Moreover, the principle of cooperation is frequently mentioned in the context of building military capabilities, which constitutes another distinctive feature of the EUGS.

Many scholars and experts have pointed out that the EUGS emphasized building the military capacities of the EU. ${ }^{12}$ Indeed, the lexical analysis supports this assessment - the frequency of the word defence (or defend) increased significantly from 9 (which gave it 40th position on the rank list) to 51 (15th), while the frequency of the word security decreased slightly (from 2nd in 2003 to 3rd position in 2016). Furthermore, the document stresses the importance of cooperation in

9 See for instance subsection 3.3 of the EUGS.

10 Council of the European Union, Shared Vision, Common Action: A Stronger Europe - A Global Strategy for the European Union's Foreign And Security Policy, Brussels 2016, p. 30.

11 Ibidem, p. 3.

12 J. Legrand, Does the New EU Global Strategy Deliver on Security and Defence?, 2016, <http://www.europarl.europa.eu/RegData/etudes/IDAN/2016/570472/EXPO_IDA (2016)570472_EN.pdf.> 
the context of building defense capabilities - cooperative effort should contribute to achieving interoperability, effectiveness, the ability to act autonomously and, therefore, to build the credibility of the EU. All in all, cooperation (and its inflected forms) is the 5th most frequently used word (74 mentions) and predominantly appears in the context of defense. ${ }^{13}$ At the same time, the term was almost absent under the previous strategy (8 mentions). The cooperation framework refers as much to the Member States as to other partners, notably the United States, UN, NATO as well as neighbouring countries.

Regarding internal cooperation, the EUGS proposes an exploration of opportunities for enhanced cooperation with a view to establishing a structured form of cooperation in the future. ${ }^{14}$ Although not directly mentioned, this clearly refers to the Permanent Structured Cooperation (PESCO) foreseen in articles 42.6 and 46 TEU. ${ }^{15}$ The European Council emphasized on several occasions that "any capabilities developed through PESCO will remain owned and operated by the Member States”16 and reminded that the cooperation within PESCO has to be consistent with the commitments agreed within NATO and the UN. In December 2017

13 Member States remain sovereign in their defence decisions: nevertheless, to acquire and maintain many of these capabilities, defence cooperation must become the norm. The EU will systematically encourage defence cooperation and strive to create a solid European defence industry, which is critical for Europe's autonomy of decision and action. See Council of the European Union, Shared Vision, Common Action: A Stronger Europe - A Global Strategy for the European Union's Foreign And Security Policy, p. 11. Europeans must be able to protect Europe, respond to external crises, and assist in developing our partners'security and defence capacities, carrying out these tasks in cooperation with others. See ibidem, p. 19. While defence policy and spending remain national prerogatives, no Member State can afford to do this individually: this requires a concerted and cooperative effort. See ibidem, p. 20.

14 Defence cooperation between Member States will be systematically encouraged. See ibidem, p. 46. If successful and repeated over time, this might lead to a more structured form of cooperation, making full use of the Lisbon Treaty's potential. See ibidem, p. 48.

15 Council of the European Union, European Council Conclusions on Security and Defence, 22 June2017, para. 8, <http://www.consilium.europa.eu/en/press/press-releases/2017/06/22/ euco-security-defence/>.

16 Council of the European Union, Council Conclusions on Implementing the EU Global Strategy in the Area of Security and Defence, 6 March 2017, para. 6, <http://www.consilium.europa.eu/en/press/press-releases/2017/03/06/conclusions-security-defence/>. 
Council of the European Union adopted a decision establishing PESCO and determining the list of participating Member States. ${ }^{17}$ In the joint declaration, Member States expressed their intention to collaborate on 17 initial projects. ${ }^{18}$

Within the defence cooperation framework, the EUGS emphasizes the role of research and technology $(R \& T)^{19}$ - something that was entirely absent under the strategy of $2003 .{ }^{20}$ Call for the development of R\&T in the area of defence was further operationalized in the European Defence Action Plan adopted in 2016. ${ }^{21}$ Finally, this was reflected in the Council decision establishing PESCO (14866/17), in which Member States committed inter alia to increase "the share of expenditure allocated to defence R\&T with a view to nearing the $2 \%$ of total defence spending.”22 Thus, it should be not surprising that the European Commission plans to spend $€ 500$ million a year on defence R\&T, starting from $2021 .{ }^{23}$ Nor should it be if the EU launches a fully-fledged European Defence Research Programme 2021-2017 with a budget as high as $€ 3.5$ billion. $^{24}$

Emphasis on cooperation between all the stakeholders rather than centralization when building the defense capabilities of the EU corre-

17 Council of the European Union, Shared Vision, Common Action, p. 11.

18 Declaration on PESCO projects, available: <http://www.consilium.europa.eu/media/32020/ draft-pesco-declaration-clean-10122017.pdf $>$. For the brief description of the projects see $<$ http://www.consilium.europa.eu/media/32079/pesco-overview-of-first-collaborative-ofprojects-for-press.pdf $>$.

19 Crucially, EU funding for defence research and technology (...) will prove instrumental in developing the defence capabilities Europe needs. A sustainable, innovative and competitive European defence industry is essential for Europe's strategic autonomy and for a credible CSDP. See Council of the European Union, Shared Vision, Common Action: A Stronger Europe -A Global Strategy for the European Union's Foreign And Security Policy, 2016, p. 46.

20 There was no mention of research in the strategy of 2003, while the term appeared 11 times under the EUGS. Hence, the TF-IDF score for the term is relatively high $(2,36)$.

21 Council of the European Union 2016, op. cit, p. 19.

22 Ibidem. See Annex II, par. 4.

23 J. Mawdsley, The Emergence of the European Defence Research Programme, in: The Emergence of EU Defense Research Policy. Innovation, Technology, and Knowledge Management, eds N. Karampekios, I. Oikonomou, E. Carayannis, Washington 2018, p. 209.

24 D. Fiott, EU Defence Research in Development, "European Union Institute for Security Studies” 2016, no. 1. 
sponds closely with the conceptual framework for resilience. Scholars researching complex systems ${ }^{25}$ point out that decentralized and non-hierarchical structures are more resilient to potential attacks. ${ }^{26}$ The resilience of a network structure increases with the number of connections between the nodes ${ }^{27}$ (in the context of the EUGS - between Member States and their neighbourhood) and allows for avoiding situations such as when an attack on the best-connected node (for instance, a cyberattack on the EU institutions) affects the functionality of the whole system.

The inherent complexity of resilience and its role in building sustainability

The meaning of the term resilience ${ }^{28}$ in the EUGS was a subject of numerous discussions - many studies emphasized its ambiguity or vagueness $^{29}$ and called for its refinement. ${ }^{30}$ Nevertheless, the concept of resil-

25 As a discipline, complex systems is a new field of science studying how parts of a system and their relationships give rise to the collective behaviors of the system, and how the system interrelates with its environment. See the definition: Y. Bar-Yam, General Features of Complex Systems, in: Knowledge Management, Organizational Intelligence and Learning, and Complexity, ed. L.D. Kiel, vol. I, Oxford 2009, p. 354.

26 A. Reka, J. Hawoong, A. Barabasi, Error and Attack Tolerance of Complex Networks, "Nature” 2000, no. 409, pp. 378-382.

27 Consequently, resilience is governed by three topological characteristics, where dense, symmetric and heterogeneous networks are most resilient, and sparse, antisymmetric and heterogeneous networks are least resilient. See J. Gao, B. Barzel, B. Barabási, Universal Resilience Patterns in Complex Networks, "Nature” 2016, no. 530, pp. 307-312.

28 The term "resilience" was coined by the ecologist C.S. Holling as early as in 1973 and was then defined as "a measure of the persistence of systems and of their ability to absorb change and disturbance and still maintain the same relationships between populations or state variables”. See Crawford Stanley Holling, Resilience and Stability of Ecological Systems, Annual Review of Ecology and Systematics 4, no. 1 (November 1973), p. 14, https:// doi.org/10.1146/annurev.es.04.110173.000245. Some scholars underline that the concept of resilience has been developed simultaneously in the fields of ecology, psychology (mainly child development and children's ability to recover from trauma) and epidemiology (ability to sustain health). See M. Welsh, Resilience and Responsibility: Governing Uncertainty in a Complex World, “The Geographical Journal” 2014, no. 1, pp. 15-26. The concept of resilience subsequently expanded to the social and economic systems. See Council of the European Union 2016, op. cit., p. 11.

29 A.E. Juncos, Resilience as the New EU Foreign Policy Paradigm: A Pragmatist Turn?, "European Security" 2017, no. 1(26), p. 3.

30 C. Altafin, V. Haász, K. Podstawa, The New Global Strategy for the EU’s Foreign and Security Policy at a Time of Human Rights Crises, "Netherlands Quarterly of Human Rights” 
ience is nothing new in EU rhetoric, and its frequency in various EU documents has been increasing rapidly since 2009. According to the EUR-Lex (the most complex database covering EU documents), the term resilience was mentioned in 128 documents in 2009. This number increased to 320 in the year preceding the adoption of the EUGS. In the last two years, the growing tendency significantly strengthened (581 documents in 2017) and this increase was arguably prompted by the new strategy. Nevertheless, the EUGS should be interpreted not as a stand-alone document but as a consequence of a long-term trend. Moreover, the concept of resilience was steadily spreading not only into the EU rhetoric - this tendency reflected a global increase in the popularity of this term ${ }^{31}$; the concept has also been previously introduced to the security strategies of various Member States, e.g. France (2013), United Kingdom (2015), Germany (2016).

Any attempt to understand the concept of resilience will, inevitably, lead to systems theory (and, most of all, to complex systems theory). Although the EUGS does not explicitly propose the application of systems theory to security and defense, it refers to states and societies - and both are nothing other than highly sophisticated systems with individuals, communities, political institutions, economies, environmental and energy resources as their components. In other words, both are complex systems. Moreover, various EU documents and instructions refer to the OECD’s studies ${ }^{32}$, which expressis verbis propose a systems approach and introduce "resilience systems analysis" as a tool for policymakers. ${ }^{33}$

A complex systems approach focuses on "how parts of a system and their relationships give rise to the collective behaviors of the system, and how the system interrelates with its environment." ${ }^{34}$ It seems that the

2017, no. 2(35), p. 5.

31 According to Google N-gram Viewer, there was a gradual increase in the use of word 'resilience' in the period 1970-1990. Since 1990 the growth has been exponential.

32 See for instance: European Commission, Operating in Situations of Conflict and Fragility. An EU Staff Handbook, Brussels/Luxembourg, 2015. See also: Council of the European Union 2016, op. cit., p. 20.

33 OECD, Guidelines for Resilience Systems Analysis - Facilitation Guide, 2014, p. 5.

34 Yaneer Bar-Yam, General Features... 
EUGS is underpinned with a similar logic - it underlines the role of the Member States (parts of the system) and the cooperation between them (the relationships) as a precondition for building a resilient EU (the collective behavior of the system) and emphasizes the nexus between the external and internal threats (how the system interrelates with its environment). If we find the theory of complex systems to be applicable to the EUGS, we can justify, for instance, the multidimensionality of resilience. As Lance H. Gunderson and C.S. Holling propose, the complexity of the challenges to the specific system requires analysis of interactions among three to five sets of variables, each operating at a qualitatively distinct speed. ${ }^{35}$ Reducing sets of variables to two, however convenient for the analysis, misses the complexity of interactions and interdependencies between the various variables. Therefore, simplification may lead to an inadequate understanding of the emerging challenges and, as a consequence, to wrongfully designed policies. Thus, the concept of resilience, if we agree on the relevance of the complex systems approach, has to be multidimensional. This conclusion, in consequence, invalidates arguments stressing the ambiguity or vagueness of the concept of resilience.

Furthermore, complex systems theory may shed a new light on the nexus between resilience and sustainability. Although resilience has been named as the leitmotif of the EUGS ${ }^{36}$, the lexical analysis reveals that the frequency of the term sustainable increased identically (and, respectively, its TF-IDF score). While the previous strategy did not mention it even once, the term appeared 31 times in the EUGS. Moreover, the document suggests a close relationship between resilience and sustainable development, stating that: "[a] resilient society featuring democracy, trust in institutions, and sustainable development lies at the

35 L.H. Gunderson and C.S. Holling, Panarchy: Understanding Transformations in Human and Natural Systems, Washington 2002, pp. 69-71.

36 M. Sanders, Obama's Principled Pragmatism, Contemporary Pragmatism 8, no. 2 (April 2011), pp. 31-42. 
heart of a resilient state." ${ }^{37}$ This is neither a coincidence nor a surprise, since the linkages between the two concepts have been the subject of numerous studies ${ }^{38}$ touching upon various fields (e.g. environment ${ }^{39}$, economy ${ }^{40}$, emergency management ${ }^{41}$ ). The relation between these two concepts has been the subject of numerous theoretical considerations ${ }^{42}$, including publications building on the theory of complex systems. ${ }^{43}$ What may be beneficial for the EU policymakers from these discussions is the fundamental difference between both concepts - while building sustainability needs to have a specific long-term goal (e.g. Sustainable Development Goals) ${ }^{44}$, building resilience cannot have one, as the future threats to the stability of the system are not known. Thus, resilience should focus on training the general ability to withstand and recover from shock. Interestingly, the EUGS dropped the class of strategic objectives that was used in the previous strategy and replaced it with the more general class of goals with an overarching goal to build a sustainable and resilient Union. Many studies emphasize that sustainability

37 Council of the European Union, Shared Vision, Common Action: A Stronger Europe A Global Strategy for the European Union's Foreign And Security Policy, 2016, p. 8.

38 "Resilience theory emphasizes that change is as normal a condition for social-ecological systems as stability, and a system may exist in multiple stable states. The goal is to enable a system to respond to changing conditions so that there are minimal losses to the system and to its essential functioning. External shocks or emergent stresses pushing the system over a threshold may prompt the changing condition. [... S Similar to a resilience approach, sustainability analyses understand the biophysical drivers and constraints on a system's future, but focus on and measure change in terms of human decisions, institutional dynamics, and shared attitudes.” See Council of the European Union 2016, p. 46. See also: European Commision, European Defence Action Plan.

39 C. Altafin, V. Haász, K. Podstawa, The New Global Strategy..., p. 142.

40 Y. Bar-Yam, General Features...

41 Council of the European Union, European Security Strategy: A secure Europe in a better world, 2003, p. 2.

42 Ibidem, p. 11.

43 Ibidem, p. 14.

44 Interestingly, the preamble of the Agenda 2030 mentions both concepts together: We are determined to take the bold and transformative steps which are urgently needed to shift the world onto a sustainable and resilient path. See UN General Assembly, Transforming our world: the 2030 Agenda for Sustainable Development, 21 October 2015, A/RES/70/1, $<$ http://www.refworld.org/docid/57b6e3e44.html>. 
requires resilient components such as a resilient environment, a resilient economy and a resilient society. ${ }^{45}$ Otherwise, development may be easily undone. As we will show further in this study, those three components receive the lion's share of the EU narrative on resilience.

\section{Case Study: Multidimensionality of Resilience in the EU Rhetoric at the UN Fora}

As many scholars have pointed out, under the EUGS the term resilience appears in various contexts, which may lead to confusion over its factual meaning. The European Parliament has recently removed some of these doubts by the adoption of a resolution on resilience as a strategic priority of the external action of the EU. ${ }^{46}$ The resolution underlines the importance of the OECD's resilience "systems analysis framework" (para. 3) and stresses its multidimensional nature: human, economic, environmental, political, security and societal (para. 4). Although these dimensions remain undefined, they clearly build on the OECD's Guidelines for Resilience System Analysis, which applies, however, slightly different terminology. The OECD distinguishes the following components of system resilience: financial (e.g. banking facilities, employment), human (e.g. knowledge, education, health), natural (e.g. environment, agriculture, minerals), physical (e.g. energy, infrastructure), political (e.g. knowledge of rights and duties, political participation) and social (e.g. formal and informal social interaction). While the OECD's financial and natural components have counterparts in the EU's economic and environmental dimensions, the EU's element of security seems to be broader than the OECD's physical component. The OECD's physical component emphasizes the resilience of the material infrastructure and does not mention the resilience of cyberspace at all. The EU's security dimension, on the other hand, stresses the importance

45 M. Welsh, Resilience and Responsibility: Governing Uncertainty in a Complex World, “The Geographical Journal” 2014, no. 1.

46 European Parliament resolution of 1 June 2017 on resilience as a strategic priority of the external action of the EU (2017/2594(RSP)). 
of cyber resilience, which encompasses both critical infrastructure management as well as building the resilience of cyberspace (against e.g. cyber espionage or propaganda). In order to investigate, if the EU adheres to the framework outlined above, we examined the

\section{EU's Activity in the United Nations Between July 2014 and December 2019}

So far, the adoption of resilience as the strategic priority under the EUGS, was indeed reflected in the EU interventions ${ }^{47}$ at the United Nations, but only for a short period of time following the adoption of the strategy (Table 3). The term appeared in the 20 out of 69 EU statements (29\%) made between January and June 2017, while in the preceding two years the frequency did not exceed 14\%. Nevertheless, since July 2017 a share of interventions mentioning resilience drastically decreased and varied between 8.9\% (July-December 2017) and 13.5\% (January-June 2019). One explanation is that the period following launching the EUGS was accompanied by general excitement with a new strategy, and thus its leitmotif was perhaps overused. In this light, the subsequent decrease in the second half of 2017 may be the result of the realization that overexploitation may degrade resilience to the point where it becomes merely a buzzword rather than a guiding principle.

The analysis of the EU's rhetoric at the UN leads to the conclusion that the multidimensional nature of resilience needs to be further clarified, particularly in the areas of strengthening the security of critical infrastructure and cyberspace as well as the political fabric of society. The concept of resilience was most frequently referred to in the contexts of environmental challenges (mainly climate change mitigation ${ }^{48}$ and

47 Analysis encompassed statements made by the EU, including joint statements. All documents have been extracted from the official website of the Delegation of the European Union to the United Nations in New York.

48 Delegation of the European Union to the United Nations in New York, EU Statement United Nations Open-ended Informal Consultative Process on Oceans and Law of the Sea, 
Small Island Developing Countries ${ }^{49}$ ), humanitarian aid operations, ${ }^{50}$ and the protection of vulnerable groups (mainly women ${ }^{51}$ and refugees ${ }^{52}$ but since 2018 also young people ${ }^{53}$ ). Recently, more emphasis has been placed on the building of a resilient economy (e.g. low-emissions economy $^{54}$, and a resilient labour market ${ }^{55}$ ). These findings correspond with the lists of the EU priorities for the UN General Assembly, in which resilience rhetoric is present primarily in the contexts of environmental protection, sustainable development and disaster recovery. ${ }^{56}$

15 May 2017, EUUN17-045EN. EU Intervention: United Nations - PGA expert level meeting on Water, 22 March 2017, EUUN17-024EN.

49 Delegation of the European Union to the United Nations in New York, EU Statement - United Nations 2nd Committee: Sustainable Development and UN-Habitat, 15 October 2014, EUUN14-153EN. EU Statement by Commissioner Piebalgs - United Nations 3rd International Conference on Small Island Developing States: Plenary, 1 September 2014, EUUN14-106EN.

50 Delegation of the European Union to the United Nations in New York, EU Statement - United Nations General Assembly: Famine Response and Prevention, 14 April 2017, EUUN17-030EN.

51 Delegation of the European Union to the United Nations in New York, EU Statement - United Nations General Assembly: Global awareness of the tragedies of irregular migrants in the Mediterranean basin, with specific emphasis on Syrian asylum seekers, 7 April, 2017, EUUN17-029EN.

52 Delegation of the European Union to the United Nations in New York, EU Statement United Nations 3rd Committee: Report of the UN High Commissioner for Refugees, 2 November 2016, EUUN16-184EN.

53 Delegation of the European Union to the United Nations in New York, EU Statement United Nations General Assembly: Youth and Migration, 26 February 2019.

54 Delegation of the European Union to the United Nations in New York, EU Statement United Nations High-Level Meeting on Climate Change and the Sustainable Development Agenda, 23 March 2017, EUUN17-025EN. EU Commissioner Crețu at the Opening Plenary Session of the UN Habitat Conference, 18 October 2016, EC16-1018.

55 Delegation of the European Union to the United Nations in New York, EU Statement United Nations 3rd Committee: Social Development, 4 October 2016, EUUN16-118EN.

56 The list for the 71st GA mentions security (peace), the resilience of communities and governments, humanitarian assistance; 70th GA - environmental protection, low carbon and resilient economy; 69th GA - community resilience to disasters and conflicts, 68th GA - resilience of societies and economies, climate resilient low carbon development, community safety and resilience to disasters and conflicts; 67th - no mentions; 66th - resilience of the vulnerable and fragile countries; 65th and 64th - no mentions.

57 Context labels have been assigned manually by the author after thorough review of the statements that mentioned the word resilience/resilient at least once. One statement could have been classified into two categories if resilience was mentioned more than once and in various contexts. If terms resilience/resilient were mentioned more than once, but in the same context, such a statement was classified only to one category. 
Table 3. Presence of the term 'resilience/resilient' in EU statements and interventions delivered at the UN fora between January 2014 and December 2019. Source: the author's elaboration.

\begin{tabular}{|c|c|c|c|c|c|c|c|c|c|c|}
\hline \multirow[b]{2}{*}{ 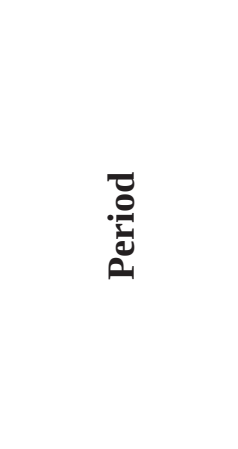 } & \multirow{2}{*}{ 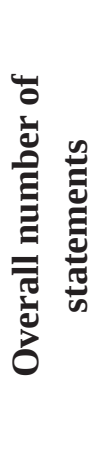 } & \multirow{2}{*}{ 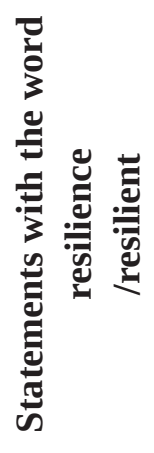 } & \multirow{2}{*}{ 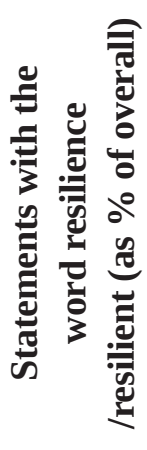 } & \multicolumn{7}{|c|}{$\begin{array}{l}\text { Context in which the re- } \\
\text { silience was mentioned } \\
\text { (dimension) }^{57}\end{array}$} \\
\hline & & & & 苞 & 总 & : & 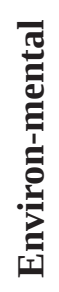 & 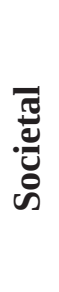 & 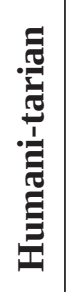 & \\
\hline 2019 (Jul-Dec) & 141 & 16 & 11,3 & 1 & 4 & 0 & 3 & 3 & 1 & 4 \\
\hline 2019 (Jan-Jun) & 104 & 14 & 13,5 & 2 & 3 & 1 & 3 & 5 & 1 & 3 \\
\hline 2018 (Jul-Dec) & 121 & 13 & 10,7 & 1 & 2 & 0 & 2 & 3 & 3 & 3 \\
\hline 2018 (Jan-Jun) & 108 & 14 & 13,0 & 4 & 4 & 1 & 1 & 6 & 5 & 1 \\
\hline 2017 (Jul-Dec) & 135 & 12 & 8,9 & 1 & 4 & 1 & 1 & 5 & 1 & 1 \\
\hline 2017 (Jan-Jun) & 69 & 20 & 29,0 & 5 & 3 & 4 & 5 & 6 & 7 & 2 \\
\hline 2016 (Jul-Dec) & 131 & 13 & 9,9 & 3 & 2 & 2 & 4 & 2 & 3 & 2 \\
\hline 2016 (Jan-Jun) & 99 & 14 & 14,1 & 3 & 1 & 2 & 6 & 2 & 4 & 2 \\
\hline 2015 (Jul-Dec) & 108 & 13 & 12,0 & 2 & 1 & 0 & 7 & 3 & 2 & 2 \\
\hline 2015 (Jan-Jul) & 107 & 13 & 12,1 & 0 & 2 & 1 & 3 & 3 & 4 & 1 \\
\hline 2014 (Jul-Dec) & 134 & 21 & 15,4 & 0 & 2 & 1 & 8 & 3 & 5 & 3 \\
\hline 2014 (Jan-Jun) & 91 & 14 & 15,4 & 0 & 0 & 3 & 2 & 2 & 8 & 1 \\
\hline Overall & 1348 & 177 & 13.1 & 19 & 21 & 15 & 39 & 35 & 42 & 18 \\
\hline
\end{tabular}

What is significant for the EU's narrative is the importance of the nexus between the environmental, economic and humanitarian dimensions, which apparently constitute core elements of resilience building. ${ }^{58}$ Some may say that the EU rhetoric at the UN fora is determined by

58 Delegation of the European Union to the United Nations in New York, EU Statement United Nations General Assembly: Famine Response and Prevention, 14 April 2017, EUUN17-030EN. 
the challenges on the UN agenda (such as the Ebola outbreak, climate change and the fulfillment of the SDGs) and that is why other elements are set aside. Nevertheless, the analysis of the EU documents on resilience confirms there is a strong attachment to the abovementioned elements. For instance, the recent European Parliament resolution on resilience as a strategic priority of the external action of the EU clearly prioritizes the humanitarian dimension and the need for empowering vulnerable groups, mainly women. ${ }^{59}$ The EU's Action Plan for Resilience in Crisis Prone Countries 2013-2020 is more multidimensional, but remains limited to the humanitarian, environmental and societal perspectives. The broadest approach may be found in the document entitled "A Strategic Approach to Resilience in the EU's external action” adopted by the European Commission in June 2017. So far, this is the only document that put equal emphasis on all the elements, including the political ${ }^{60}$ and security dimensions. ${ }^{61}$

\section{The Role of Principles and Values Under the EUGS - Where are Human Rights?}

The EUGS frequently, and in various contexts, refers to principles (28 mentions in the EUGS, compared to zero in the previous strategy). The document emphasizes that the principles will guide the EU's external action ${ }^{62}$, that in the promotion of shared interests, the EU will adhere to clear principles ${ }^{63}$ and that the EU will engage in a practical

59 European Parliament resolution of 1 June 2017 on resilience as a strategic priority of the external action of the EU (2017/2594(RSP)).

60 European Commission, Joint Communication to the European Parliament and the Council: A Strategic Approach to Resilience in the EU's external action, 7 June 2017, JOIN(2017) 21 final, pp. 3, 7.

61 Ibidem, pp. 15-17.

62 Ibidem, 3.

63 J. Legrand, Does the New EU Global Strategy Deliver on Security and Defence?, 2016, <http://www.europarl.europa.eu/RegData/etudes/IDAN/2016/570472/EXPO_IDA (2016)570472_EN.pdf >. 
and principled way in peacebuilding. ${ }^{64}$ Those principles include but arguably are not limited to: accountability, representativeness, responsibility, effectiveness and transparency. ${ }^{65}$ Turning towards principles and rules - absent from the previous strategy - confirms that the EU is facing a period of high uncertainty and seeks to minimize potential turbulence. Indeed, in recent years the EU did not necessarily follow formerly established principles, e.g. in the case of Ukraine, the EU had been consistently moving away from democratic conditionality and subsequently abandoned it in November 2013, due to fears that the country would come under the Russian sphere of influence. ${ }^{66}$ Taking into consideration rising autocratic tendencies in neighboring countries (e.g. Turkey), as well as in the EU itself (e.g. Poland, Hungary), the EU's reaffirmed commitment to principles, rules, and values is being put to the test.

The concept of "principled pragmatism" requires special attention. This proposed approach to foreign policy aims at striking a balance between realism and idealism, isolationism and interventionism. ${ }^{67}$ Although proposed as one of the leitmotifs of the EUGS, principled pragmatism is not an entirely new concept. For instance, Barack Obama adopted it as a guiding principle for US diplomacy. ${ }^{68}$ Even before than that, in the early 2000s it emerged at the intersection of international human rights law and business. It was originally defined by John Ruggie as "an unflinching commitment to the principle of strengthening the promotion and protection of human rights as it relates to businesses, coupled with

64 Council of the European Union, Shared Vision, Common Action: A Stronger Europe A Global Strategy for the European Union's Foreign And Security Policy, 2016, p. 11.

65 Ibidem, p. 19.

66 Ibidem, p. 20.

67 In charting the way between the Scylla of isolationism and the Charybdis of rash interventionism, the EU will engage the world manifesting responsibility towards others and sensitivity to contingency. See ibidem, p. 46.

68 Ibidem, p. 48. Paul Richard Huard, “Principled Pragmatism: Fredrik Logevall on Obama’s Legacy”, The National Interest, 23 May 2016, <http://nationalinterest.org/feature/principled-pragmatism-fredrik-logevall-obamas-legacy-16312>. Recent National Security Strategy of the United States of America, adopted in December 2017 and signed by Donald Trump, operates with an equivalent 'principled realism'. 
a pragmatic attachment to what works best in creating change where it matters most — in the daily lives of people." ${ }^{69}$ The EUGS does not offer its own definition, limiting itself to the vague remark that principle pragmatism "stems as much from a realistic assessment of the strategic environment as from an idealistic aspiration to advance a better world." Thus, principled pragmatism may be interpreted per analogiam as the concept that integrates the need for the protection of values (idealistic dimension) and common sense in choosing the means to achieve the goal (realistic dimension).

John Ruggie, as well as the Obama administration (most notably Hilary Clinton), linked principled pragmatism with one specific value, namely human rights. ${ }^{71}$ As the lexical analysis has shown, the same is the case with the EUGS - human rights are the single most frequently mentioned value (26 times), followed by democracy (21 mentions), and the rule of law (6 mentions). Interestingly, in the strategy of 2003, the presence of values was marginal - democracy was invoked five times, the rule of law three times and human rights only twice. This remarkable rejuvenation of human rights may indicate the way in which principled pragmatism will be addressed - more emphasis will be put on the protection of human rights than on building democratic institutions.

Some may invoke a historical analogy to the Helsinki Accords of 1975, when the Western World's pursuit of human rights jeopardized the decline of communist regimes in Eastern Europe and the USSR. Americans were conscious that advocating for human rights may bring better long-term results than calling for the free elections or adopting the rule of law. The latter was aimed directly at the destruction of state apparatus, thus the USSR would have been more resistant to engage in

69 UN Economic and Social Council, Interim Report of the Special Representative of the Secretary-General on the Issue of Human Rights and Transnational Corporations and other Business Enterprises, E/CN.4/2006/97, para. 81.

70 Council of the European Union, European Council Conclusions on Security and Defence, para. 8.

71 Council of the European Union, Council Conclusions on Implementing the EU Global Strategy in the Area of Security and Defence, para. 6. 
any constructive dialogue. Even more interestingly, L. Garment (former U.S. Representative to the United Nations Commission on Human Rights) perceived human rights as a tailor-made diplomatic instrument aimed at non-resilient states. During his hearing before the Commission on Security and Cooperation in Europe in February 1977, he emphasized that: "They are not prepared to yield on them. The strength of their society is thin, the ability to withstand crises, economic crises, food, crises, ultimately human rights crises, is precarious, and therefore they will make a real issue of our right to press for implementation of agreements arrived at in Helsinki." ${ }^{22}$

The difference is that this time human rights appear not as a weapon against non-democratic regimes, but primarily as a remedy for the EU's eroded credibility and effectiveness in approaching its neighborhood. Therefore, placing human rights high on the agenda is a consequence of the adoption of principled pragmatism and resilience as guiding principles for the EUGS. The interdependency of these concepts is being consistently reaffirmed in various EU documents. For instance, the European Parliament resolution on resilience as a strategic priority of the external action of the EU not only emphasizes the role of human rights in building resilience but stresses the need to "focus on results" in this matter. ${ }^{73}$ While human rights were mentioned seven times throughout the text of the resolution, the other values (democracy and the rule of law) were invoked only three times in total.

One may ask if the values of democracy and the rule of law are not compatible (or less compatible) with the concepts of either principled pragmatism or resilience? Yet democracy and respect for the rule of law in the EU's neighborhood undeniably serve its geopolitical interests. Democratic regimes are more stable prosperous and - to use

72 Hearings before the Commission on Security and Cooperation in Europe, ninety-fifth Congress, First Session on the Implementation of the Helsinki Accords, vol. I, 23-24 February 1977, p. 12.

73 European Parliament resolution of 1 June 2017 on resilience as a strategic priority of the external action of the EU (2017/2594(RSP)). 
EU language - resilient than autocracies. Nevertheless, the promotion of democracy aspires to spark a systemic change at the level of governance, which often meets with resistance from the ruling elites. The review of the European Neighborhood Policy confirms that it also requires a tailor-made approach with each and every country. Thus, democratization is a complex and rather evolutionary process of transformation that encompasses inter alia strengthening human rights and the rule of law. Human rights, on the other hand, are aimed primarily at the protection of individuals from arbitrary state actions. They are far better conceptualized and operationalized in dozens of international human rights treaties and other instruments adopted since 1945. Moreover, the EU remains only one among many international actors that advocates for human rights protection. Thus, support for human rights can bring better results in a considerably shorter time, which closely corresponds with the reasons behind the adoption of the concept of resilience. The EU's priority is, after all, the mitigation of fragility - both internal and external - and the crisis rhetoric (best exemplified by the frequency of occurrence of must) only confirms that the EU intensely seeks stability for Europe. All the abovementioned factors explain the rejuvenation of human rights narration under the EUGS and, at the same time, provoke questions over the democratic component of resilience.

\section{Conclusions}

Comparative analysis of the European Security Strategy of 2003 and the European Union Global Strategy of 2016 unveils significant differences in their lexical layers. Those differences are reflected, to some extent, in the subsequently adopted documents and policies. The EUGS underlines inter alia the necessity of developing defense capabilities, building resilience, and the affirmation of principled pragmatism as a guide for the EU's external actions. As the following documents adopted by the European Parliament (e.g. resolution on resilience as a strategic priority of 
the external action of the $\mathrm{EU}^{74}$ ) and European Commission (e.g. European Defence Action Plan ${ }^{75}$ ) indicate, those are not merely empty rhetoric, but substantive commitments that are being consistently implemented.

Nevertheless, not all of the commitments established under the EUGS are equally translated nto action. On one spectrum, there is the area of defence, where the EU's strong commitment is best demonstrated by the proposed budget allocation of $€ 3.5$ billion for the period 2021-2027. Furthermore, the establishment of PESCO remains in accordance with the affirmation of the cooperation framework highlighted under the EUGS. Somewhere in the middle, there is the concept of resilience, which is indeed frequently mentioned in numerous EU documents, but the recent increase may very well be a continuation of a long-term fascination with this concept and not the result of its inclusion in the EUGS. Indeed, the analysis of the EU interventions at the UN fora indicates that the concept of resilience was present in the EU rhetoric in the period preceding its adoption (2014-2015). Although there was a sharp increase in the frequency of mentions of this term in the first half of 2017, the following months have witnessed a significant drop. This may suggest that the EU still needs better operationalization of this concept. On the other end of the spectrum, there is principled pragmatism which itself rarely appears in the EU documents and rhetoric. As C. Altafin, V. Haász, and K. Podstawa noticed, although human rights are present in the textual layer of the EUGS, their role in the European grand Strategy is not clear. ${ }^{76}$

The textual analysis of the EUGS allowed the extraction of the most frequent terms that together create a net of interlinked concepts (e.g. resilience, human rights) and phrases (e.g. cooperation, the prevalence of plural nouns when describing threats and problems). The theory of complex systems explains many of the relations between them and may even be more useful in the further operationalization of concepts such

\section{Ibidem.}

75 Y. Bar-Yam, General Features...

76 Council of the European Union, Shared Vision, Common Action: A Stronger Europe A Global Strategy for the European Union's Foreign And Security Policy, 2016, p. 46. 
as resilience or principled pragmatism. Nevertheless, the complexity of the EUGS will arguably pose problems for policymakers and EU diplomacy, as we saw with the example of EU interventions at UN fora.

\section{References}

Altafin C., Haász V., Podstawa K., The New Global Strategy for the EU's Foreign and Security Policy at a Time of Human Rights Crises, “Netherlands Quarterly of Human Rights” 2017, no. 2(35).

Bar-Yam Y., General Features of Complex Systems, in: Knowledge Management, Organizational Intelligence and Learning, and Complexity, ed. L.D. Kiel, Oxford 2009.

Fiott D., EU Defence Research in Development, "European Union Institute for Security Studies” 2016.

Gao J., Baruch Barzel, and Albert-László Barabási, Universal Resilience Patterns in Complex Networks, "Nature” 2016, no. 530.

Gunderson L.H., Holling C.S., Panarchy: Understanding Transformations in Human and Natural Systems, Washington 2002.

Holling C.S., Resilience and Stability of Ecological Systems, “Annual Review of Ecology and Systematics” 1973, no. 1.

Huard P. R., Principled Pragmatism: Fredrik Logevall on Obama's Legacy, "The National Interest” 23 May 2016.

J. Legrand, Does the New EU Global Strategy Deliver on Security and Defence?, 2016, <http://www.europarl.europa.eu/RegData/etudes/ IDAN/2016/570472/EXPO_IDA(2016)570472_EN.pdf>.

Juncos A.E., Resilience as the New EU Foreign Policy Paradigm: A Pragmatist Turn?, “European Security” 2017, no. 1(26).

Mawdsley J., The Emergence of the European Defence Research Programme, in: The Emergence of EU Defense Research Policy. Innovation, Technology, and Knowledge Management, eds N. Karampekios, I. Oikonomou, E. Carayannis, Washington 2018. 
Ramos J., Using TF-IDF to Determine Word Relevance in Document Queries, 1999.

Reka A., Hawoong J., Barabasi A.L., Error and Attack Tolerance of Complex Networks, "Nature" 2000, no. 409.

Salton G., M.J. MacGill, Introduction to Modern Information Retrieval, McGraw-Hill 1983.

Sanders M., Obama’s Principled Pragmatism, “Contemporary Pragmatism” 2011, no. 2.

Welsh M., Resilience and Responsibility: Governing Uncertainty in a Complex World, “The Geographical Journal” 2014, no. 1.

Council of the European Union, Council Conclusions on Implementing the EU Global Strategy in the Area of Security and Defence, 6 March 2017.

Council of the European Union, European Council Conclusions on Security and Defence, 22 June 2017.

Council of the European Union, European Security Strategy: A Secure Europe in a Better World, 2003.

Council of the European Union, Shared Vision, Common Action: A Stronger Europe - A Global Strategy for the European Union's Foreign And Security Policy, 2016.

Declaration on PESCO projects, <http://www.consilium.europa.eu/media/32020/draft-pesco-declaration-clean-10122017.pdf > .

Delegation of the European Union to the United Nations in New York, EU Commissioner Crețu at the Opening Plenary Session of the UN Habitat Conference, 18 October 2016, EC16-1018.

Delegation of the European Union to the United Nations in New York, EU Intervention: United Nations - PGA expert level meeting on Water, 22 March 2017, EUUN17-024EN.

Delegation of the European Union to the United Nations in New York, EU Statement - United Nations 2nd Committee: Sustainable Development and UN-Habitat, 15 October 2014, EUUN14-153EN. 
Delegation of the European Union to the United Nations in New York, EU Statement - United Nations 3rd Committee: Report of the UN High Commissioner for Refugees, 2 November 2016, EUUN16-184EN. Delegation of the European Union to the United Nations in New York, EU Statement - United Nations 3rd Committee: Social Development, 4 October 2016, EUUN16-118EN.

Delegation of the European Union to the United Nations in New York, EU Statement - United Nations General Assembly: Famine Response and Prevention, 14 April 2017, EUUN17-030EN.

Delegation of the European Union to the United Nations in New York, EU Statement - United Nations General Assembly: Global awareness of the tragedies of irregular migrants in the Mediterranean basin, with specific emphasis on Syrian asylum seekers, 7 April, 2017, EUUN17-029EN.

Delegation of the European Union to the United Nations in New York, EU Statement - United Nations General Assembly: Youth and Migration, 26 February 2019.

Delegation of the European Union to the United Nations in New York, EU Statement - United Nations High-Level Meeting on Climate Change and the Sustainable Development Agenda, 23 March 2017, EUUN17-025EN. Delegation of the European Union to the United Nations in New York, EU Statement - United Nations Open-ended Informal Consultative Process on Oceans and Law of the Sea, 15 May 2017, EUUN17-045EN. Delegation of the European Union to the United Nations in New York, EU Statement by Commissioner Piebalgs - United Nations 3rd International Conference on Small Island Developing States: Plenary, 1 September 2014, EUUN14-106EN.

European Commission, Joint Communication to the European Parliament and the Council: A Strategic Approach to Resilience in the EU's external action, 7 June 2017, JOIN(2017) 21 final.

European Commission, Operating in Situations of Conflict and Fragility. An EU Staff Handbook, Brussels/Luxembourg, 2015. 
European Commission's Science and Knowledge Service, Competence Centre on Text Mining and Analysis, <https://ec.europa.eu/jrc/en/ text-mining-and-analysis>.

European Parliament resolution of 1 June 2017 on resilience as a strategic priority of the external action of the EU (2017/2594(RSP)).

Hearings before the Commission on Security and Cooperation in Europe, ninety-fifth Congress, first session on the implementation of the Helsinki Accords, vol. I, 23-24 February 1977, p. 12.

OECD, Guidelines for Resilience Systems Analysis - Facilitation Guide, 2014.

TIBCO Statistica, <http://statistica.io/>.

UN Economic and Social Council, Interim Report of the Special Representative of the Secretary-General on the Issue of Human Rights and Transnational Corporations and other Business Enterprises, E/CN.4/2006/97.

UN General Assembly, Transforming our world: the 2030 Agenda for Sustainable Development, 21 October 2015, A/RES/70/1.

\section{SUMMARY}

\section{Mining the EU Global Strategy of 2016}

This study proposes to apply an automated lexical analysis to the European Security Strategy of 2003, entitled "A Secure Europe in a Better World”, and the European Union Global Strategy of 2016, entitled "Shared Vision, Common Acton: A Stronger Europe". The findings are not limited to supporting the predominant interpretations of scholars and experts, but aim at exploring the usefulness of text mining techniques in the interpretation of EU documents. Furthermore, the conclusions drawn from the lexical analysis are discussed in the light of complex systems theory, which may be beneficial for the proper understanding of the concept of resilience (mainly its multidimensional nature) 
and its subsequent operationalization. The last part of the paper includes an in-depth analysis of the EU rhetoric on the UN fora (period: 20142019) regarding the concept of resilience, in particular its linkages with human rights.

Keywords: European Union, United Nations, resilience, systems theory, human rights, text mining, security.

Łukasz Szoszkiewicz, Institute of Law Studies of the Polish Academy of Sciences, Poznań Human Rights Centre, Mielżyńskiego 27/29, 61-725 Poznań, Republic of Poland, e-mail: lukasz.szoszkiewicz@amu.edu.pl.

DOI 10.14746/ppuam.2020.11.11 